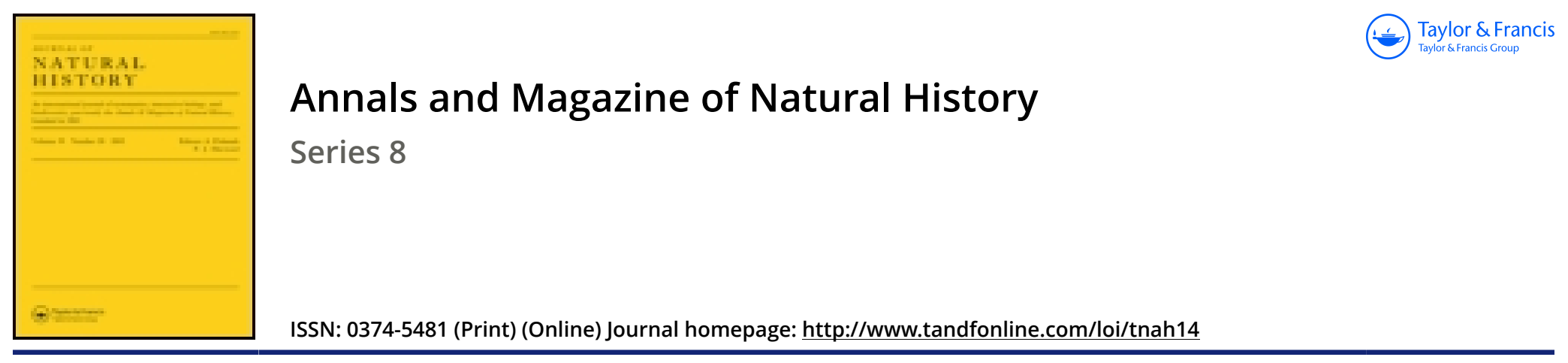

\title{
XVI.-Descriptions of some new species of Heterocera, chiefly from tropical South America
}

\section{Herbert Druce F.L.S.}

To cite this article: Herbert Druce F.L.S. (1911) XVI._Descriptions of some new species of Heterocera, chiefly from tropical South America , Annals and Magazine of Natural History, 8:43, 138-150, DOI: $10.1080 / 00222931108693007$

To link to this article: http://dx.doi.org/10.1080/00222931108693007

$$
\text { Published online: } 08 \text { Sep } 2009 .
$$

Submit your article to this journal $\square$

Џ Article views: 7

Q View related articles ¿

Citing articles: 2 View citing articles 둔 
XVI.-Descriptions of some new Species of Heterocera, chiefly from Tropical South America. By HerberT DRUCE, F.L.S. \&c.

Fam. Syntomidæ.

Mesothen doris, sp. n.

Male-Head, collar, tegulæ, thorax, abdomen, and legs pale sellow; antennes black; palpi pale yellow, with black tips; abdomen with a central row of black spots. Primaries hyaline, the costal margin pale yollow, the veins at the base yellow beyond and the margins of the wing black: secondaries hyaline, the reins and margins black, the fringe black.

Expanse $1 \frac{1}{2}$ inch.

Hab. Colombia, Monte del Edna, 5000 feet (Mus. Druce).

Subfam. ARCTINAR.

Metaretia palcemon, sp. n.

Male.-Head, collar, tegulæ, thorax, and abdomen chromeyellow; antenne and anus blackish brown; legs chromeyellow. Primaries hyaline, the basal half of the wing chromeyellow, the veins, the costal margin at the apex, and the fringe black : secondaries chrome-yellow, bordered with black at the apex and partiy round the outer margin. Underside very similar to the upperside.

Expanse 1 inch.

Hab. West Africa, Bitji, Ja River, Cameroons, 2000 feet (Mus, Druce).

Automolis pinon, sp. $\mathrm{n}$.

Female. - Head, antennæ, collar, tegulæ, and thorax yellowish grey; abdomen pinkish yellow; the underside and legs pale yellow. Primaries bright pink; a large round yellow spot at the end of the cell and an oval-shaped yellow spot on the inner margin near the base; the outer margin from the apex nearly to the anal angle broadly bright yellow : secondaries pale yellow. Underside as above, but rather deeper in colour.

Expanse $1 \frac{1}{2}$ inch.

Hab. South Brazil, Alto da Serra Santos, 2600 feet (Mus. Druce).

Allied to Automolis roseofasciata, Drace. 


\section{Opharus superba, sp. $\mathrm{n}$.}

Male.-Head, antennæe, palpi, and legs black; collar black, edged with orange; tegula grey, edged with black; thorax black, clothed with orange-red hairs; abdomen chromeyellow, the three middle segments black above, the underside of the anus black. Primaries fawn-colour, the veins black; five bands of broken orange irregular spots edged with black cross the wing from the costal to the inner margin, the inner margin black at the base to about the middle; a black spot at the anal angle; the fringe black and yellow : secondaries chrome-yellow, broadly bordered with black from the apex to the anal angle; a rather large crescent-shaped black spot at the end of the cell. Underside very similar to the upperside. Expanse $3 \frac{1}{4}$ inches.

Hab. South Brazil, Alto da Serra Santos, 2600 feet (Mus. Druce).

A very distinct species allied to Opharus chorima, Schaus.

\section{Virbia palmeri, sp. n.}

Male-Head, collar, tegulæ, thorax, and upperside of the abdomen very dark brown, the sides of the abdomen yellow; legs dark brown; antennæ black. Primaries dark brown, irrorated with yellowish scales: secondaries chrome-yellow, broadly bordered with black from the apex to the anal angle, where it is widest, and deeply dentated on the inner edge. Underside: primaries as above, secondaries rather paler.Female the same as the male.

Expanse $1 \frac{1}{2}$ inch.

Hab. W. Colombia, San Antonio, 5800 feet (Mus. Druce).

\section{Virbia punctata, sp. n.}

Male.-Head, collar, tegulæ, thorax, and legs dark brown; abdomen black, the sides yellow. Primaries dark brown; a yellow spot at the end of the cell; the fringe yellowish brown: secondaries chrome-yellow, bordered with black, widest at the anal angle. Underside of the primaries yellow, bordered with dark brown; secondaries very similar to the upperside.

Expanse $1 \frac{1}{2}$ inch.

Hab. Colombia, Siato, Rio Siato; slopes of Choco, 5200 feet (Mus. Druce). 


\section{Virbia epione, sp. $\mathrm{n}$.}

Male.-Head, collar, tegulæ, and thorax pale brown; antennæ, abdomen, and legs black, sides of the abdomen yellow. Primaries pale brown : secondaries black, yellow on the inner margin; a rather wide yellow streak forked at the end extends from the base to just beyond the cell; the fringe yellow.

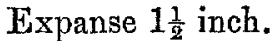

Hab. S.E. Peru, Santo Domingo, 6000 feet (Mus. Druce).

Virbia birchi, sp. n.

Male.-Head, antennæ, collar, tegulæ, thorax, abdomen, and legs black; the sides of abdomen yellow. Primaries black : secondaries black, with a central yellow streak from the base to beyond the cell ; the fringe of both wings black. The underside of the primaries yellow, bordered with black.

Expanse $1 \frac{3}{4}$ inch.

Hab. Caparo, W. Central Trinidad; Colombia, Cacagualito, 1500 feet (Mus. Druce).

Tirbia underwoodi, sp. n.

Male.-Head, antennæ, collar, tegulæ, thorax, abdomen, and legs black. Primaries black, darkest at the base: secondaries pale yellow, narrowly edged with black from the apex to vein 3, then widely banded with black to the inner margin. The underside of the primaries with a large round yellow spot at the end of the cell; secondaries as above.

Expanse 2 inches.

Hab. Costa Rica, Carrillo (Mus. Druce).

Fam. Notodontidæ.

Farigia nana, sp. n.

Male.-Head, collar, tegulæ, thorax, and upperside of the abdomen grey, thickly irrorated with black hairs; antennæ brown, the shaft white; underside of the abdomen and legs yellowish white. Primaries pale brown, thickly irrorated with green and grey scales, grey on the costal margin near the base; an indistinct greenish-brown waved band extends from the costal margin near the apex to the inner margin nearest the anal angle; a marginal waved black line from the apex to the anal angle; the fringe pale fawn-colour : secondaries pale brown, yellowish at the base and along the 
inner margin. Underside : primaries very pale brown, dark brown on the costal margin; secondaries uniformly yellowish white.

Expanse $1_{\frac{3}{4}}$ inch.

Hab. S.E. Peru, Santo Domingo, 6000 feet (Mus. Druce). Allied to Farigia tulana, Schaus.

\section{Farigia baladan, sp. n.}

Female.-Head, collar, tegulæ, and thorax grey ; abdomen pale brown, irrorated with grey hairs. Primaries grey, thickly irrorated with bright green scales, crossed from the costal to the inner margin by three fine waved black lines; the wing partly shaded with very pale brown beyond the cell; a round black spot between veins 2 and 3 ; the fringe blackish grey : secondaries dark brown, slightly yellowish at the base. Underside: both wings aniformly dark brown.

Expanse $2 \frac{1}{2}$ inches.

Hab. S.E. Peru, Santo Domingo, 6000 feet; Quinton, Carabaya, 5000 feet (Mus. Druce).

\section{Farigia medan, sp. n.}

Male-Head, collar, tegulæ, and thorax greenish grey ; abdomen and antennæ greyish brown; underside of the abdomen and legs pale brown. Primaries brown, thickly irrorated with green scales about the middle; the base of the wing broadly grey; the fringe dark brown: secondaries dark brown. Underside of both wings pale whitish brown.

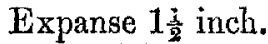

Hab. Colombia, El Tigre, Rio Tamaua; Choco, 350 feet (Mus. Druce).

A small species allied to Farigia nana, Druce.

Farigia larissa, sp. n.

Female-Head, collar, and teguløe white; thorax and abdomen brown, the anal segments greyish ; legs pale brown. Primaries dark brown, the outer third of the wing white; a large greyish spot at the end of the cell, edged with white; a round reddish-brown spot between veins 2 and 3 and one between 3 and 4; a submarginal black line extends from the apex to the anal angle; the fringe brownish grey : secondaries brown, the veins dark brown. Underside of both wings dark brown.

Expanse $2 \frac{1}{4}$ inches.

Hab. Colombia, Juntas, Rio Tamana, Rio San Juan; Choco, 400 feet (Mus. Druce). 


\section{Farigia xenopithia, sp. n.}

Ma7e.-Head, collar, tegulæ, underside of thorax, and legs. pale fawn-colour mixed with greenish hairs; upperside of the abdomen dark brown, underside yellow. Primaries dark blackish brown, thickly irrorated with greenish scales; a series of small black spots along the inner margin ; four small green spots edged with black on the costal margin; a waved black line extends from the apex to the anal angle; three elongated brown spots at the apex: secondaries dark reddish brown. Underside of all the wings uniformly pale pinkish brown.

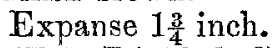

Hab. Trinidad, Caparo (Mus. Druce).

Hippia cinga, sp. n.

Male-Head and collar grey-brown; antennæ, palpi, tegulæ, and thorax dark brown; abdomen above dark blackish brown, underside pale brown; legs brown, banded with white. Primaries dark blackish brown, irrorated with a few black scales; a pale long greyish patch at the apex, extending along the costal margin to the middle; a marginal row of pale brown spots from the apex to the anal angle; the fringe dark brown : secondaries dark brown, the fringe pale fawncolour. Underside: both wings pale brown; secondaries yellowish at the base.

Expanse 2 inches.

Flab. Chanchamayo, 1000-1500 metres (Mus. Druce).

Allied to Rippia astuta, Schaus.

\section{Drugera mimica, sp. n.}

Male.-Head, antennæ, collar, tegulæ, thorax, and upperside of the abdomen dark greyish brown; underside of the abdomen and legs yellowish brown. Primaries pale grey-brown, dark brown on the costal margin near the base, the basal part of the wing streaked with black; a band of lunular-shaped white spots edged with black crossing from the costal to the inner margin beyond the cell; a marginal row of black dots extends from the apex to the anal angle; the marginal line black; the fringe pale greyish brown: secondaries dark reddish brown; the fringe pale fawn-colour. Underside of borh wings pale brown, the costal margin of the secondaries yellowish.

Expanse 2 inches. 
Hab. Colombia, Juntas, Rio Tamaua, Rio San Juan; Choco, 400 feet (Mus. Druce).

Allied to Drugera morona, Druce.

\section{Dicentria Klagesi; sp. $\mathrm{n}$.}

Male.-Head, antennæ, palpi, collar, tegulæ, and thorax dark brown; abdomen black, the two anal segments pale fawn-colour; underside of the abdomen brownish white; legs pale brown. Primaries pale fawn-colour, irrorated with brown scales; the base of the wing greyish black; a large black spot at the end of the cell; the fringe fawn-colour: secondaries white, the costal margin and apex grey, the inner margin greyish, with a black spot on the anal angle. Underside of both wings greyish white, the costal margin shaded with brown.

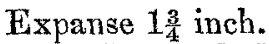

Hab. Trinidad, Caparo (S. M. Klages, Mus. Druce).

\section{Heterocampa tricolor, sp. n.}

Male.-Head, antennæ, palpi, collar, tegulæ, thorax, abdomen, and legs greenish brown. Primaries cream-colour, the basal third of the wing greenish brown : secondaries white, irrorated with green scales on the costal margin; the fringe white. Underside of both wings white, the costal margin of the primaries edged with yellow.

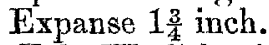

Hab. W. Colombia, San Antonio, 5800 feet (Mus. Druce).

\section{Heterocampa gilboa, sp. $\mathrm{n}$.}

Male.-Head, antennæ, collar, tegulæ, thorax, and legs greenish brown; abdomen above blackish brown, the anal segments greenish brown; the underside of the abdomen sordid white. Primaries white, the base greenish brown, thickly irrorated with white scales; a greenish-brown band crosses the wing beyond the middle, widest on the costal margin, becoming quite narrow at the anal angle; the apex and outer margin shaded with green : secondaries white, the costal margin and fringe greenish. Underside of both wings white; a dark brown mark on the costal margin of the primaries beyond the cell.

Expanse 13 inch.

Hab. S.E. Peru, Santo Domingo, 6000 feet (Mus, Druce). 
Heterocampa splendens, sp. $\mathrm{n}$.

Male-Head, palpi, tegulæ, and thorax pinkish grey; collar yellowish; antennæ brown; abdomen above pale brown, the sides yellow, underside sordid white, the anal segments clothed with grey hairs; underside of the thorax and legs grey. Primaries pale fawn-colour, pinkish grey at the base, crossed from the costal to the inner margin by a series of waved black lines, the first four near the base, the second three beyoud the cell; a series of black spots between the veins extend from the apex to the anal angle; a waved black marginal line: secondaries chrome-yellow, broadly bordered with blackish grey from the apex to the anal angle. Underside of both wings white, pale yellow at the base: primaries with a dark brown wide line crossing the wing beyond the cell from the costal margin to vein 2 .

Expanse 23 inches.

Hab. S. Brazil, Rio (Mus. Druce).

\section{Heterocampa semialba, sp. n.}

Male.-Head, palpi, and collar grey, tegulæ white ; antennæ greyish brown; thorax and abdomen dark grey, the sides of the abdomen and the anus white; legs and underside of the thorax white. Primaries dark grey, the base white irrorated with grey scales; a waved black line crosses the wing beyond the cell from the costal to the inner margin, beyond which is a large broad white patch that does not extend to the apex or anal angle; a marginal black waved line extends from the apex to the anal angle; the white mark is slightly clouded in the middle by a few grey scales; fringe black and white: secondaries white, greyish at the anal angle. Underside of both wings white; primaries clouded with grey along the costal margin.

Expanse 2 inches.

Hab. E. Peru, Chanchamayo, 2000 met. (Mus. Druce).

\section{Psilagon cincia, sp. n.}

Male.-Head, collar, tegulæ, upperside of abdomen, and legs dark brown; thorax and antennæ pale brown, the anus yellowish green. Primaries greyish white, irrorated with grey and greenish-yellow scales; the base greenish yellow, crossed by three curved dark brown lines; the inner margin thickly clothed with greenish-yellow scales: secondaries white, a greenish-yellow spot at the apex and a few black 
hairs on the inner margin. Underside: both wings sordid white.

Expanse 2 inches.

Hab. S.E. Peru, Santo Domingo, 6000 feet (Mus. Druce).

\section{Psilagon melita, sp. $\mathrm{n}$.}

Male.-Head, palpi, collar, tegrala, thorax, abdomen, and legs yellowish green; underside of the abdomen white; antennæ brown. Primaries greenish grey; a reddish-brown band extends from the middle of the inner margin up to the median vein, where it divides and forms a $Y$-shaped mark extending to the costal margin; a submarginal row of white spots with black points from the apex to the anal angle; the fringes reddish brown: secondaries white, the fringe white. Underside of both wings white; the costal margin of the primaries yellowish.

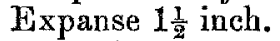

Hab. S.E. Peru, Santo Domingo, 6000 feet (Mus. Druce).

Urgerda chaon, sp. $\mathrm{n}$.

Male-Head, palpi, collar, tegulæ, and thorax pale brownish green, thickly irrorated with yellowish hairs; antennæ pale brown; abdomen reddish brown; anus greenish. Primaries pale brown, thickly irrorated with black and green scales; two small white spots at the end of the cell and a submarginal row of whitish dots extending from the apex to the anal angle; the marginal line black : secondaries reddish brown, palest at the base. Underside of primaries reddish brown, of the secondaries creamcolour.

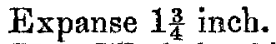

Hab. W. Colombia, San Antonio, 5800 feet; S.E. Pera, Santo Domingo, 6000 feet (Mus. Druce).

Urgerda luceria, sp. $\mathrm{n}$.

Male.-Green; antennæ brown; collar grey, odged with black and white; tegulw and thorax green; abdomen and legs pale brown. Primaries grey, irrorated with black scales; the subcostal vein green; a green band crossing the wing near the base, a second green band, edged with black on the inner side, beyond the cell, crossing the wing from the costal to the inner margin; a submarginal row of black points extending from the apex to the anal angle; the fringe dark grey : secondaries greyish brown. Underside of both Ann.\& Mag. N. Hist. Ser. 8. Vol. viii. 10 
wings reddish brown, the costal margin of the secondaries whitish.

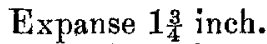

Hab. Pera, Quinton, Carabaya, 5000 feet (Mus. Druce).

\section{Urgerda brunea, sp. n.}

Mate.-Head, palpi, antennæ, collar, tegulæ, thorax, abdomen, and legs dark brown; the underside of the abdomen and anus pale brown. Primaries dark reddish brown, irrorated with pale greyish-brown scales; a whitish streak at the end of the cell; a submarginal row of rather large dark brown spots between the veins, extending from the apex to the anal angle; the fringe dark brown : secondaries blackish brown; the underside of both wings pale brown.

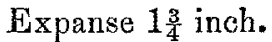

Hab. Peru, Oconeque, Carabaya, 7000 feet (Mus. Druce).

\section{Urgerda palmeri, sp. n.}

Male.-Head, collar, tegulæ, and thorax yellowish brown ; palpi and antenne black; abdomen above black, the anus yellow; underside of abdomen pale brown; legs dark brown. Primaries reddish brown, clouded with yellow at the apex, and on the inner margin three indistinct waved brown lines cross the wing from the costal to the inner margin; the outer margin from the apex to the anal angle broadly yellow, much dentated on the inner side; a fine waved white line divides the yellow and brown colour of the wing; the fringe yellow : secondaries pale yellowish grey, clouded with brown on the costal margin, apex, and outer margin; a reddishbrown spot on the anal angle; the fringe yellow. Underside: both wings yellowish white; primaries clouded with dusky brown from the base to beyond the cell; the costal margin near the apex pink : secondaries with a black spot at the anal angle.

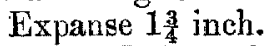

Hab. W. Colombia, San Antonio, 5800 feet (Mus. Druce).

\section{Malacampa bosttgeri, sp. n.}

Male.-Head, palpi, collar, tegulæ, and thorax very dark brown, almost black, thorax irrorated with a few green hairs; abdomen above very dark brown; anderside and legs fale brown, the anus clothed with green hairs. Primaries blackbrown, crossed beyond the cell by two waved black lines; a 
green spot at the end of the cell ; the outer and inner margins very thickly irrorated with green scales; the marginal line black: secondaries dark brown; the fringe pale brown. Underside of both wings dark brown.

Expanse 21 inches.

Hab. East Peru, Huaucabamba, 6000-10,000 feet (Mus. Drues).

\section{Meragisa julia, sp. n.}

Male.-Head, collar, tegulæ, and thorax brownish grey; antennæe and palpi dark brown; abdomen black, clothed with long yellowish hairs at the base; the anal segments dark grey ; the underside of the thorax, ab lomen, and legs yellow. Primaries dark grey, crossed by indistinct waved black lines and irrorated with black scales; a round black spot between veins 3 and 4 ; the marginal line black; the fringe yellow : secondaries black; the inner margin broadly yellow; the fringe yellow. Underside : both wings black; the costal and outer margin of both wings yellow; the base and inner margin of the secondaries yellow.

Expanse $2 \frac{1}{2}$ inches.

Hab. S.E. Peru, Santo Domingo, Carabaya, 6000 feet; Oconeque, 7000-10,000 feet (Mus. Druce).

Allied to Meragisa garlepi, Druce.

\section{Meragisa thryeston, sp. $\mathrm{n}$.}

Male.-Head, tegulæ; thorax, and abdomen grey ; abdomen clothed with yellowish hairs at the base; collar black; underside of the thorax, abdomen, and legs yellowish grey. Primaries silvery white, slightly irrorated with black scales; a pale yellow spot edged with black close to the base and two waved yellowish lines edged with black crossing the wing from the costal to the inner margin, the first near the base, the second beyond the cell; a marginal waved black line extends from the apex to the anal angle; the fringe white: secondaries black, the inner margin yellow; the fringe yellowish. Underside: primaries black, the costal, apex, and outer margin white: secondaries black; the base, costal, outer and inner margin yellowish white.

Expanse 2 inches.

Hab. S.E. Peru, La Oroya, Rio Inambari, 3000 feet (Mus. Druce).

Allied to Meragisa sidota, Schs. 


\section{Rifargia imitata, sp. n.}

Male.-Head, palpi, collar, and tegulæ dark brown; antennæ pale brown; thorax and abdomen greenish grey; legs dark brown. Primaries greenish grey, the base broadly dark brown, edged with black on the outer side; a greenishgrey spot at the base of the cell; a small brown spot close to the apex; a brown spot between veins 1 and 2 , and a rather large square-shaped dark brown spot between veins 3 and 4 ; a submarginal line of black streaks extends from the apex to the anal angle: secondaries greyish brown, darkest round the outer margin; a small black spot on the anal angle.

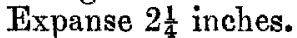

Hab. Trinidad, Caparo (Mus. Druce).

This species resembles very closely Proelymiotis aqupars, Walker.

Fam. Noctuidæ.

Acontia? superba, sp. $\mathrm{n}$.

Male.-Head, palpi, antennæ, collar, tegulæ, thorax, abdomen, and legs dark brown. Primaries dark silky brown ; the fringe dark brown: secondaries bright, glossy, dark purple; the fringe black. Underside of both wings pale brown.

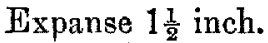

$H a b$. W. Africa, Upper Kasai District, Congo Free State (Mus. Druce).

\section{Acontia? roseipicta, sp. $\mathrm{n}$.}

Male.-Head, palpi, collar, tegulæ, thorax, and abdomen pale brown; antennæ black. Primaries pinkish fawn-colour, irrorated with black scales; a large rose-coloured spot on the middle of the inner margin, white on the inner side, edged with a black line; several small white dots at the anal angle; the fringe pinkish fawn-colour: secondaries pale brown, palest at the base. Underside pale brown, slightly irrorated with black scales.

Expanse $1 \frac{1}{4}$ inch.

Hab. W. Africa, Bitji, Ja River, Cameroons, 2000 feet, dry season (Mus. Druce). 


\section{Subfamily EUTECLINA.}

\section{Poctes chrysoplaga, sp. n.}

Male.-Head white; palpi black, the third joint white; antennæ, collar, tegulæ, thorax, and abdomen pale brown; the middle segments of the abdomen white above; the underside of the thorax and legs white. Primaries pale brown, shaded with pink at the base and apex; a curved band crosses the wing from near the apex to the middle of the inner margin; a large greenish spot on the inner margin nearest the base, and a smaller spot at the anal angle; a large dark brown curved mark on the outer margin; several minute black dots at the end of the coll and on the apex: secondaries dark brown. Underside: primaries greyish black, reddish brown at the apex: secondaries greyish white; a minute black dot at the end of the cell, below which are several very fine, waved, blackish lines, extending from near the apex to the anal angle, the outer nuargin broadly reddish brown.

Expanse $1_{\frac{3}{10}}^{3}$ inch.

Hab. S.E. Yeru, Santo Domingo, 6000 feet (G. Ockenden, Mus. Druce).

Allied to Pcectes oculatrix, Guen, from North Carolina.

\section{Marihyssa dissimilis, sp. n.}

Male.-Head, palpi, antennæ, collar, tegulæ, thorax, abdomen, and legs dark brown. Primaries pale brown, with two triangular-shaped dark brown spots (one on the costal margin small, the second on the inner margin near the base much larger), beyond which are two dark brown lines crossing the wing from the costal to the inner margin; a dark curred line close to the apex and two black dots on the anal angle; the fringe dark brown: secondaries dark brown, palest at the base and along the inner margin almost to anal angle. Underside: primaries pale greyish brown, reddish brown at the apex; a submarginal curved white line extends from the costal margin to the apex; the fringe greyish : secondaries, the costal half of the wing reddish brown, the inner half greyish brown.

Expanse $1 \frac{1}{4}$ inch.

Hab. Colombia, Minca, 2000 feet (H. H. Smith, Mus. Druce). 


\section{Tyana tenuimargo, sp. $\mathbf{n}$.}

Male.-Head, collar, tegulæ, and base of primaries white edged with red; palpi white tipped with red; antennæ brown, the base red, the edges of the tegulæ red; thorax green; abdomen and legs brownish white. Primaries pale green, the costal and outer margin edged with yellowish red, the marginal line spotted with white; a small red spot below the end of the cell: secondaries sordid white, very pale brown near the anal angle. Underside of both wings white, shaded with pale green at the base.-Female similar to the male, but with a reddish-brown spot on the costal margin nearest the base, and the spot below the cell much larger, the outer margin redder, the ground-colour of the wing striated with fine yellow lines; the secondaries pure white. Underside white, the primaries shaded with green.

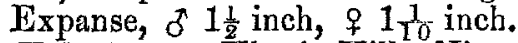

Hab. Assam, Khasia Hills, Nissary (Mus. Druoe).

\section{Carea pryeri, sp. n.}

Male-Head, palpi, antennæ, collar, tegulæ, thorax, and abdomen reddish brown, the base of the abdomen blackish brown, the anus reddish. Primaries glossy reddish brown, slightly greyish brown on the outer margin; a black spot at the end of the cell ; two dark brown lines cross the wing from the costal to the inner margin, the first nearest the base, the second beyond the cell to the anal angle: secondaries uniformly dark brown; the underside of both wings reddish brown ; primaries with a dark shade at the end of the cell.

Expanse 13 inch.

Hab. North Borneo (Pryer, Mus. Druce).

\section{Carea viridipennis, sp. n.}

Male.-Head, collar, tegulæ, and thorax olive-green; palpi and antennæ reddish brown; abdomen and legs pale brown. Primaries olive-green, crossed from the costal to the inner margin by three waved fine black lines, the first near the base, the second beyond the cell, the third submarginal, the middle line edged with greenish white on the outer side; the fringe green : secondaries and underside of both wings reddish brown.

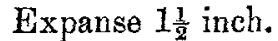

Hab. Borneo, Labuan (Pryer, Mus. Druce). 